\title{
THE
}

\section{New insights into deformation and fluid flow processes in the Nankai Trough accretionary prism: Results of Ocean Drilling Program Leg 190}

\author{
Gregory F. Moore \\ Asahiko Taira \\ Adam Klaus \\ Luann Becker \\ Babette Boeckel \\ See next page for additional authors \\ Follow this and additional works at: https://digitalcommons.uri.edu/gsofacpubs \\ Terms of Use \\ All rights reserved under copyright.
}

\section{Citation/Publisher Attribution}

Moore, G. F., A. Taira, A. Klaus, L. Becker, B. Boecker, B. A. Cragg, A. Dean, C. L. Fergusson, P. Henry, S. Hirano, T. Hisamitsu, S. Hunze, M. Kastner, A. J. Maltman, J. K. Morgan, Y. Murakami, D. M. Saffer, M. Sa'nchez-Go'mez, E. J. Screaton, D. C. Smith, A. J. Spivack, J. Steurer, H. J. Tobin, K. Ujiie, M. B. Underwood, and M. Wilson, 2001. New insights into deformation and f luid f lowprocesses in the Nankai Trough accretionary prism: Results of Ocean Drilling Program Leg 190, Geochem. Geophys. Geosyst., 2, 10.1029/2001GC000166, 2001.

Available at: https://doi.org/10.1029/2001GC000166

This Article is brought to you for free and open access by the Graduate School of Oceanography at DigitalCommons@URI. It has been accepted for inclusion in Graduate School of Oceanography Faculty Publications by an authorized administrator of DigitalCommons@URI. For more information, please contact digitalcommons-group@uri.edu. 


\section{Authors}

Gregory F. Moore, Asahiko Taira, Adam Klaus, Luann Becker, Babette Boeckel, Barry A. Cragg, Allison Dean, Christopher L. Fergusson, Pierre Henry, Satoshi Hirano, Toshio Hisamitsu, Sabine Hunze, Miriam Kastner, Alex J. Maltman, Julia K. Morgan, Yuki Murakami, Demian M. Saffer, Mario Sánchez-Gómez, Elizabeth J. Screaton, David C. Smith, Arthur J. Spivack, Joan Steurer, Harold J. Tobin, Kohtaro Ujiie, Michael B. Underwood, and Moyra Wilson 


\section{New insights into deformation and fluid flow processes in the Nankai Trough accretionary prism: Results of Ocean Drilling Program Leg 190}

\section{Gregory F. Moore}

Department of Geology and Geophysics, 1680 East-West Road, University of Hawaiì at Mānoa, Honolulu, Hawaii 96822 USA (moore@soest.hawaii.edu)

\section{Asahiko Taira}

Ocean Research Institute, University of Tokyo, 1-15-1, Minamidai, Nakano-ku, Tokyo 164-8639, Japan

\section{Adam Klaus}

Ocean Drilling Program, Texas A\&M University, College Station Texas 77845-9547 USA

\section{Luann Becker}

Hawaiì Insitute of Geophysics and Planetology, University of Hawaì at Mānoa, Honolulu, Hawaiì 96822 USA

\section{Babette Boeckel}

FB 5 Geowissenschaften, Universität Bremen, Bremen 28334 Germany

\section{Barry A. Cragg}

Department of Earth Sciences, University of Bristol, Bristol BS8 1RJ, United Kingdom

\section{Allison Dean}

Department of Geology, Western Washington University, Bellingham, Washington 98225 USA

\section{Christopher L. Fergusson}

School of Geosciences, University of Wollongong, Wollongong, NSW 2522, Australia

\section{Pierre Henry}

Département de Géologie, École Normale Supérieure, 24 rue Lhomond, Paris Cedex 0575231

France

\section{Satoshi Hirano}

Japan Marine Science and Technology Center, 2-15 Natsushimacho, Yokosuka, Kanagawa 237-0061, Japan

\section{Toshio Hisamitsu}

Ocean Research Institute, University of Tokyo, 1-15-1, Minamidai, Nakano-ku, Tokyo 164 Japan

\section{Sabine Hunze}

Geowissenschaftliche Gemeinschaftsaufgaben, Stilleweg 2, Hannover 30631, Federal Republic of Germany 


\section{Miriam Kastner}

Geoscience Research Division, Scripps Institution of Oceanography, La Jolla, California 92093-0212 USA

\section{Alex J. Maltman}

Institute of Geography and Earth Sciences, University of Wales, Aberystwyth, Aberystwyth SY23 3DB, United Kingdom

\section{Julia K. Morgan}

Department of Geology and Geophysics, Rice University, Houston, Texas 77005-1892 USA

\section{Yuki Murakami}

Graduate School of Biosphere Sciences, Hiroshima University, 1-4-4 Kagamiyama, Higashi-Hiroshima 739-8528, Japan

\section{Demian M. Saffer}

Department of Geology and Geophysics, University of Wyoming, Laramie, Wyoming 82071 USA

\section{Mario Sánchez-Gómez}

Departamento de Geología, Universidad de Jaén, Jaén 23071, Spain

\section{Elizabeth J. Screaton}

Department of Geology, University of Florida, Gainesville, Florida 32611 USA

\section{David C. Smith}

Graduate School of Oceanography, University of Rhode Island, Narragansett, Rhode Island 02882-1197 USA

\section{Arthur J. Spivack}

Graduate School of Oceanography, University of Rhode Island, Narragansett, Rhode Island 02882-1197 USA

\section{Joan Steurer}

Department of Geological Sciences, University of Missouri, Columbia, Columbia, Missouri 65211 USA

\section{Harold J. Tobin}

Department of Earth and Environmental Science, New Mexico Institute of Mining and Technology, 801 Leroy Place, Socorro, New Mexico 87801 USA

\section{Kohtaro Ujiie}

National Science Museum, 3-23-1 Hyakunin-cho, Shinjuku-ku, Tokyo 169-0073, Japan

\section{Michael B. Underwood}

Department of Geological Sciences, University of Missouri, Columbia, Columbia, Missouri 65211 USA

\section{Moyra Wilson}

Department of Geological Sciences, University of Durham, Durham, DH1 4EL, United Kingdom 
[1] Abstract: The Nankai Trough accretionary prism is considered an "end-member" prism accreting a coarse terrigenous sediment section in a setting with structural simplicity, unparalleled resolution by seismic and other geophysical techniques, and large historic earthquakes. It therefore has been the focus of Ocean Drilling Program (ODP) drilling to address several unresolved questions concerning accretionary processes and prism evolution. At six sites cored along two transects across the Nankai Trough accretionary prism during ODP Leg 190, lithostratigraphy and sediment diagenesis vary markedly. For the first time, reference sites at the seaward ends of the two transects defined the stratigraphic framework of the accreting/subducting Shikoku Basin sedimentary section. A thick section of Miocene turbidites and smectite-rich mudstone is present within the subducting section at the Ashizuri site. The turbidites and mudstones are absent in the correlative section at the Muroto site; variations in lithology, mineralogy, and hydrologic properties of the incoming sediments probably contribute to the difference in prism wedge taper between the two transects, while possibly controlling the seismic character of the active plate boundary. The décollement in both transects is localized within a common stratigraphic unit ( 5.9-7 Ma) within the lower Shikoku Basin facies. The décollement is also a major boundary for both physical and mechanical properties. A broad low-chloride pore water anomaly in the lower Shikoku Basin unit, first identified at Site 808, progressively decreases in magnitude from prism to basin along the Muroto Transect. Physical properties relationships, evidence for mineralogic changes in the sediments, and pore fluid chemistry suggest that the chloride anomaly results primarily from in situ diagenetic reactions in the sediments, possibly augmented by flow of freshened fluid from depth. New constraints on stratigraphy and age of units along more landward parts of the Muroto Transect have dramatically changed our ideas about the tectonic evolution of the prism in this area. Growth of the seaward-most part of the prism took place very rapidly, with $40 \mathrm{~km}$ of accretion within the past 2 Myr. This rate is at least 3 times greater than growth rates in a comparable prism.

Keywords: Ocean Drilling Program; subduction zone; Nankai Trough; accretionary prism.

Index terms: Marine geology and geophysics; Continental margins and sedimentary basins; Plate boundary-general.

Received April 4, 2001; Revised August 24, 2001; Accepted August 27, 2001; Published October 25, 2001.

Moore, G. F., A. Taira, A. Klaus, L. Becker, B. Boecker, B. A. Cragg, A. Dean, C. L. Fergusson, P. Henry, S. Hirano, T. Hisamitsu, S. Hunze, M. Kastner, A. J. Maltman, J. K. Morgan, Y. Murakami, D. M. Saffer, M. Sánchez-Gómez, E. J. Screaton, D. C. Smith, A. J. Spivack, J. Steurer, H. J. Tobin, K. Ujiie, M. B. Underwood, and M. Wilson, 2001. New insights into deformation and fluid flow processes in the Nankai Trough accretionary prism: Results of Ocean Drilling Program Leg 190, Geochem. Geophys. Geosyst., 2, 10.129/2001GC000166, 2001.

\section{Introduction}

[2] Earth scientists have long recognized the complex interplay of deformational, diagenetic, and hydrologic processes in developing orogenic belts and have sought to understand the controls on, and interactions among, these fundamental processes. Accretionary prisms represent unique, accessible natural laboratories for exploring initial orogenic processes. The geometries and structures of accretionary prisms are relatively simple and have been well imaged seismically. Typically, the materials incorporated within prisms are only moderately altered from their original states, so competing active processes can often be isolated, quantified, and reproduced in the laboratory. The generation of historic great earthquakes along subduction 
zones is linked to deformation within the shallower portions of accretionary prisms.

[3] The Nankai Trough accretionary prism represents an "end-member" prism accreting a terrigenous sediment section in a setting with structural simplicity, unparalleled resolution by seismic and other geophysical techniques and a long record of historic great earthquakes. It therefore represents a superb setting to address unresolved questions concerning accretionary processes and prism evolution.

[4] Ocean Drilling Program (ODP) Leg 190 was the first of a two-leg program concentrating on coring and sampling a transect of sites across and along the prism to study accretionary processes. Leg 196, which occurred in 2001, used logging-while-drilling technology to collect in situ physical properties data and also installed advanced CORKs [Davis et al., 1992] and a borehole seismometer for longterm in situ monitoring of prism processes including pressure, temperature, fluid geochemistry, and microseismicity.

[5] The results of previous studies of accretionary prisms, including the Nankai prism, have provided testable models to explain the distribution of lithology, structures and the role of diagenesis, physical properties, and fluid pressure in prism evolution. Drilling during Leg 190 addressed several of these models. Leg 190's goals were to understand the following.

\subsection{Spatial Distribution and Temporal Progression of Accretionary Prism Deformation}

[6] Most previous drilling in active prisms has concentrated on frontal thrust regions. The properties and character of the incoming sedimentary section and the nature of deformation deeper within the prism have been largely undocumented. Leg 190 drill sites included two seaward reference sites and, for the first time, sites that penetrated through the slope cover and into the deeper, landward portion of the prism. The new sites yield important age constraints on prism growth rates and structural evolution.

\subsection{Structural and Hydrologic Evolution of the Décollement Zone}

[7] Previous drilling at the toe of the Nankai prism provided insights into décollement characteristics but, with coring at only one site, provided no information on initial conditions or lateral development of this important feature. Leg 190 drill sites sampled the proto-décollement region seaward of the deformation front in two locations and the décollement in the protothrust zone, allowing us to more fully characterize the regional development of the décollement.

\subsection{Chemical Gradients and Fluid Flow Paths Within the Accretionary Prism}

[8] Drilling in other accretionary prisms has established that that warm fluids flow from the deep landward parts of the prism seaward to the trench and beyond. Geochemical profiles collected from Nankai also suggested fluid migration was important, but mechanisms and pathways were unclear. The new data from Leg 190 reveal that geochemical signatures of the pore fluids can also reflect in situ diagenesis, complicating recognition of flow conditions.

\subsection{Contrasting Stratigraphic and Deformational Framework Along Strike}

[9] Our two transects show distinctly different prism geometries that were previously attributed to differences in fluid flow and décollement strength along strike. Our new drill sites document lateral contrasts in sediment stratigraphy and physical properties that may influence deformation styles. The new data 


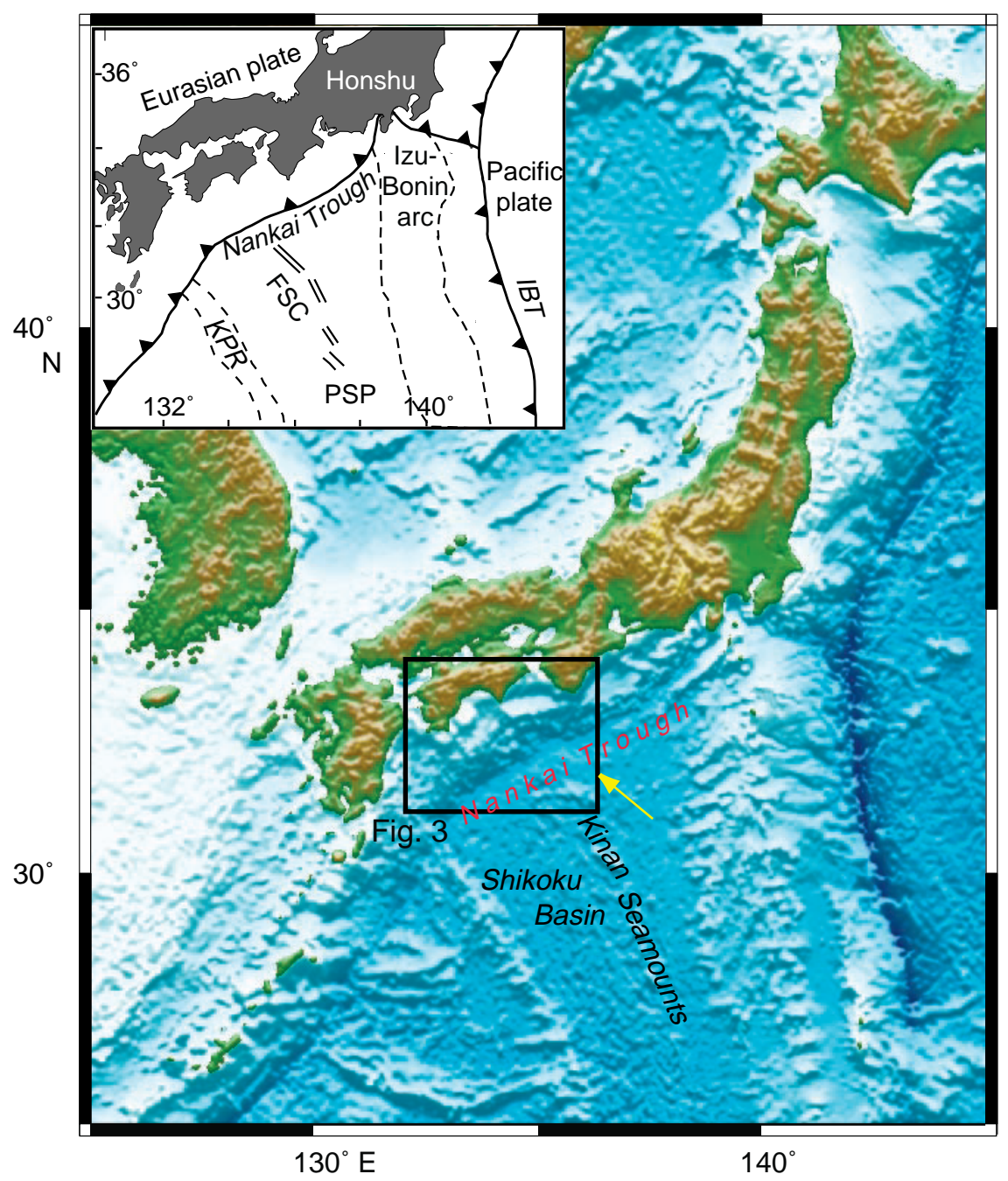

Figure 1. Shaded relief map of the Nankai Trough produced from the Hydrographic Department of Japan's topographic data set (500-m grid interval). The black box outlines the Leg 190 Nankai drilling area shown in Figure 3. The arrow shows the convergence direction of the Shikoku Basin beneath Japan. The inset shows a tectonic map of the Philippine Sea region that includes the Nankai Trough. IBT, Izu-Bonin Trench; KPR, Kyushu-Palau Ridge; PSP, Philippine Sea plate; FSC, fossil spreading center.

constrain the input into the deep seismogenic zone and its initial transformations.

\section{Geological Setting}

[10] The Japanese Island arc system is flanked to the east and south by subduction boundaries of the Pacific and Philippine Sea plates
(Figure 1). The Nankai Trough is the plate boundary between the subducting Shikoku Basin and the southwest Japan arc (Eurasian plate). The Shikoku Basin is part of the Philippine Sea plate, which is subducting to the northwest under southwest Japan at a rate of $2-4 \mathrm{~cm} / \mathrm{yr}$ [Karig and Angevine, 1986; Seno, 1977], slightly oblique to the plate margin. 


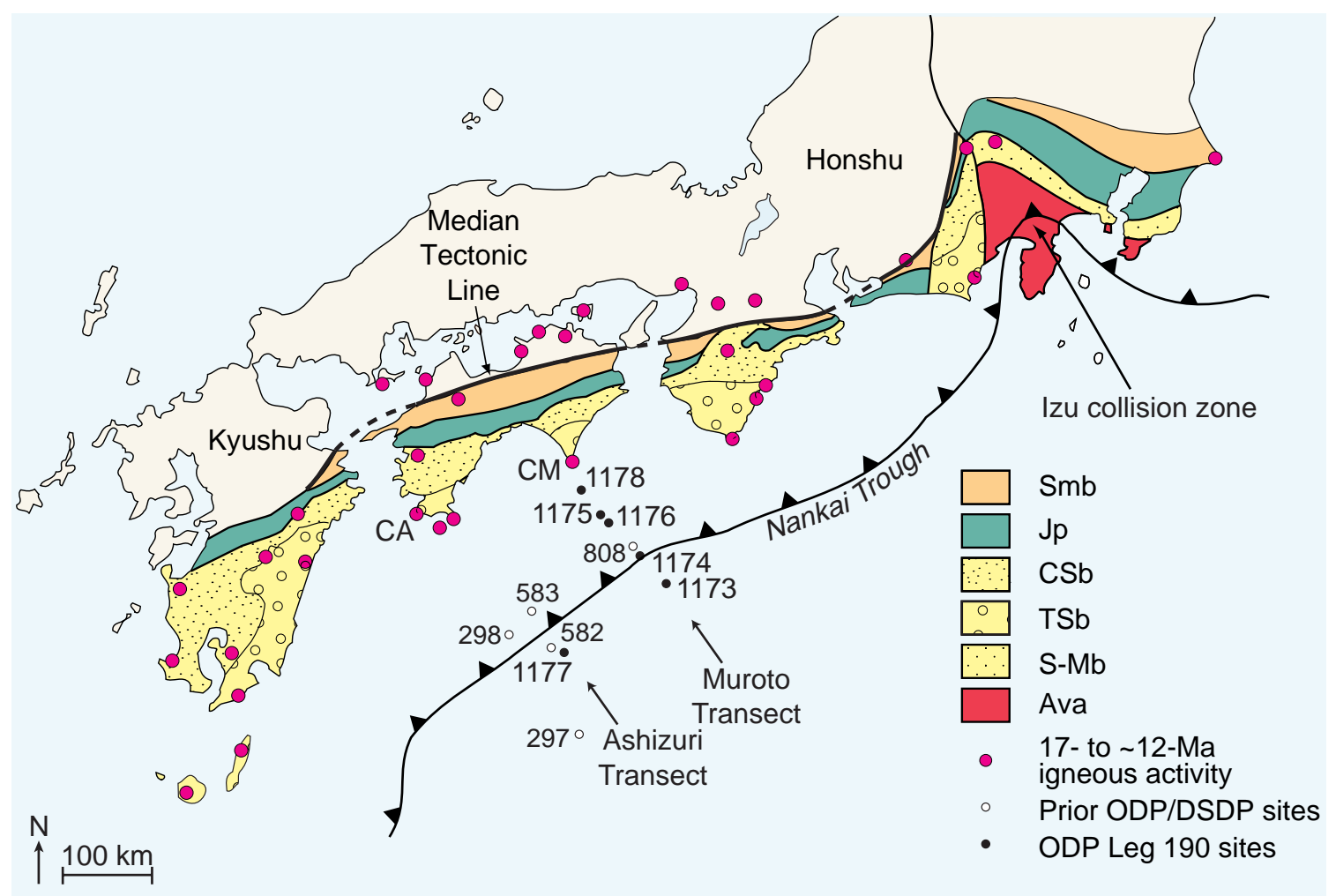

Figure 2. Geologic map of the southwest Japan forearc region and the Leg 190 Muroto and Ashizuri drilling transects. The Shimanto accretionary prism provides a landward analog of the Nankai accretionary prism. Note the widespread 17- to 12-Ma igneous activity, probably due to the initial subduction of the young Shikoku Basin oceanic lithosphere. Open circles show previous ODP/DSDP drill sites. CA, Cape Ashizuri; CM, Cape Muroto; Smb, Sanbagwa metamorphic belt; Jp, Jurassic accretionary prism; CSb, Cretaceous Shimanto belt; TSb, Tertiary Shimanto belt; S-Mb, Shimanto and Mineoka belts (undivided); Ava, Accreted volcanic arc.

[11] Active sediment accretion is presently taking place at the Nankai Trough. The record of accretion extends landward to Shikoku Island and the coastal zone of southwest Honshu, where older accretionary prism rocks are exposed (Figure 2). The Cretaceous and Tertiary Shimanto Belt, interpreted as a direct ancient analog of the Nankai accretionary prism, is characterized by imbricated thrust slices of trench turbidites and mélanges composed of ocean-floor basalt, pelagic limestone, radiolarian chert, and hemipelagic shale intermixed with highly sheared scaly shale [Taira et al., 1988]. The youngest part of the Shimanto Belt is early Miocene in age.

[12] The subducting oceanic lithosphere of the Shikoku Basin has a history related to the rifting of the proto-Izu-Bonin arc [Taylor, 1992]. The rifting started in the Oligocene and culminated in Shikoku Basin seafloor spreading that lasted until $\sim 15$ Ma. Seafloor spreading separated the remnant arc, the Kyushu-Palau Ridge, from the active IzuBonin arc, creating the Shikoku Basin [Okino et al., 1994, 1999]. 


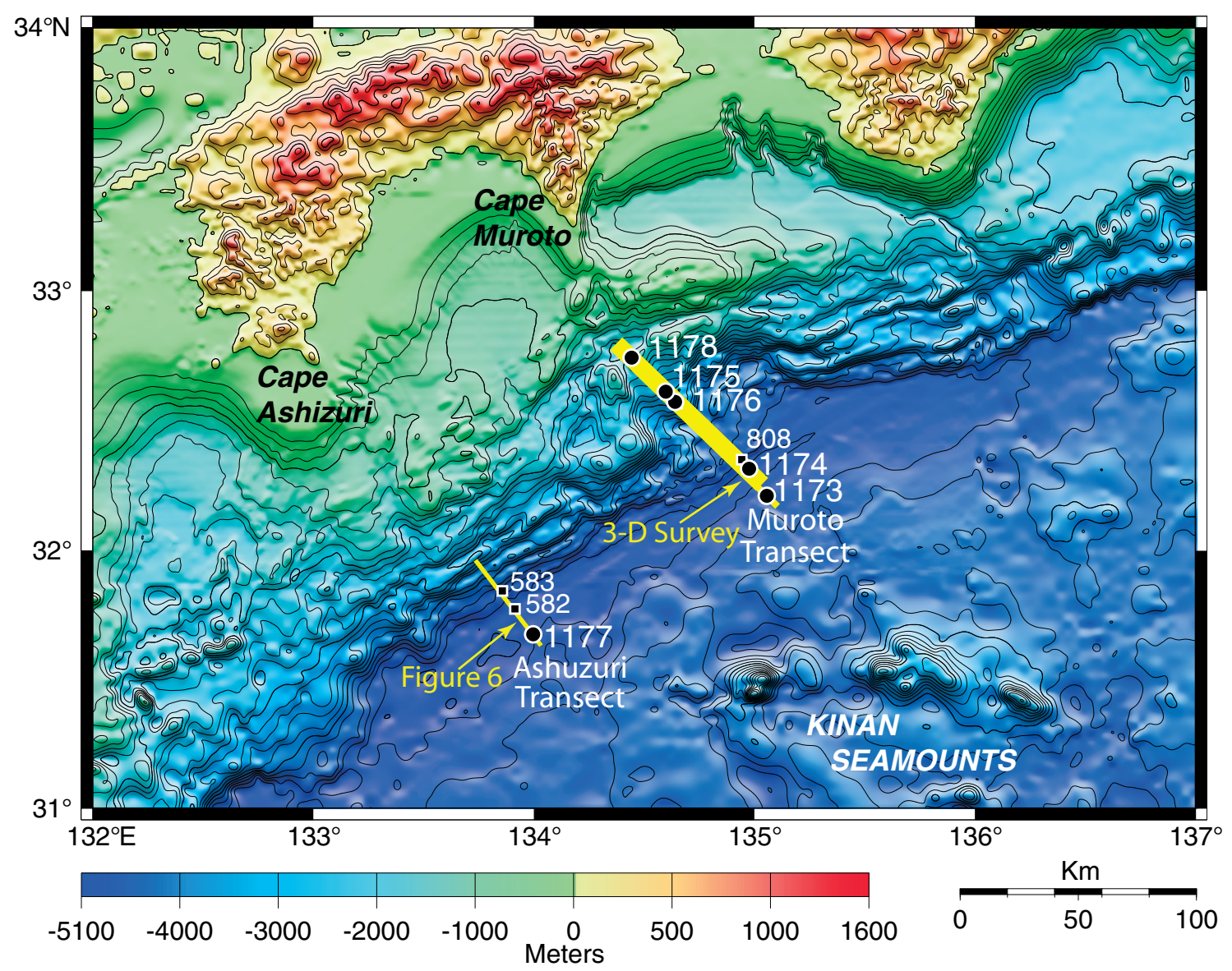

Figure 3. ODP Leg 190 (solid circles) and previous ODP/DSDP drill sites (solid squares) in the Nankai Trough. The shaded outline shows the 3-D seismic survey of Moore et al. [2001]. Contour interval is $100 \mathrm{~m}$.

[13] In southwest Japan, widespread igneous activity took place at $17-12 \mathrm{Ma}$ within the forearc, close to the trench [Kano et al., 1991] (Figure 2). This episode, including high-Mg andesite emplacement, is generally interpreted as reflecting injection of hot asthenosphere and initial subduction of the young Shikoku Basin seafloor [Takahashi, 1999]. Widely distributed volcanic activity, which started $\sim 8$ Ma in southern Kyushu and by $6 \mathrm{Ma}$ in southwest Japan, suggests the establishment of a volcanic front and a deeply penetrating subducting slab [Kamata and Kodama, 1994]. In the Izu Collision Zone, the accretion of the Tanzawa massif (part of the volcanic front of the Izu-Bonin arc) started at $\sim 8 \mathrm{Ma}$, with the main phase of collision at $\sim 6-5 \mathrm{Ma}$ [Niitsuma, 1989]. Erosion of the rapidly uplifted collision zone supplied coarse detritus down the Nankai Trough axis [Taira and Niitsuma, 1986; Underwood et al., 1993]. Subduction of the Shikoku Basin and offscraping of the trench sediment wedge formed a frontal accretionary prism to the southwest Japan forearc (Nankai Trough accretionary prism [Taira et al., 1992; Le Pichon et al., 1987]).

[14] One of the prominent topographic features in the vicinity of the Leg 190 sites is an 


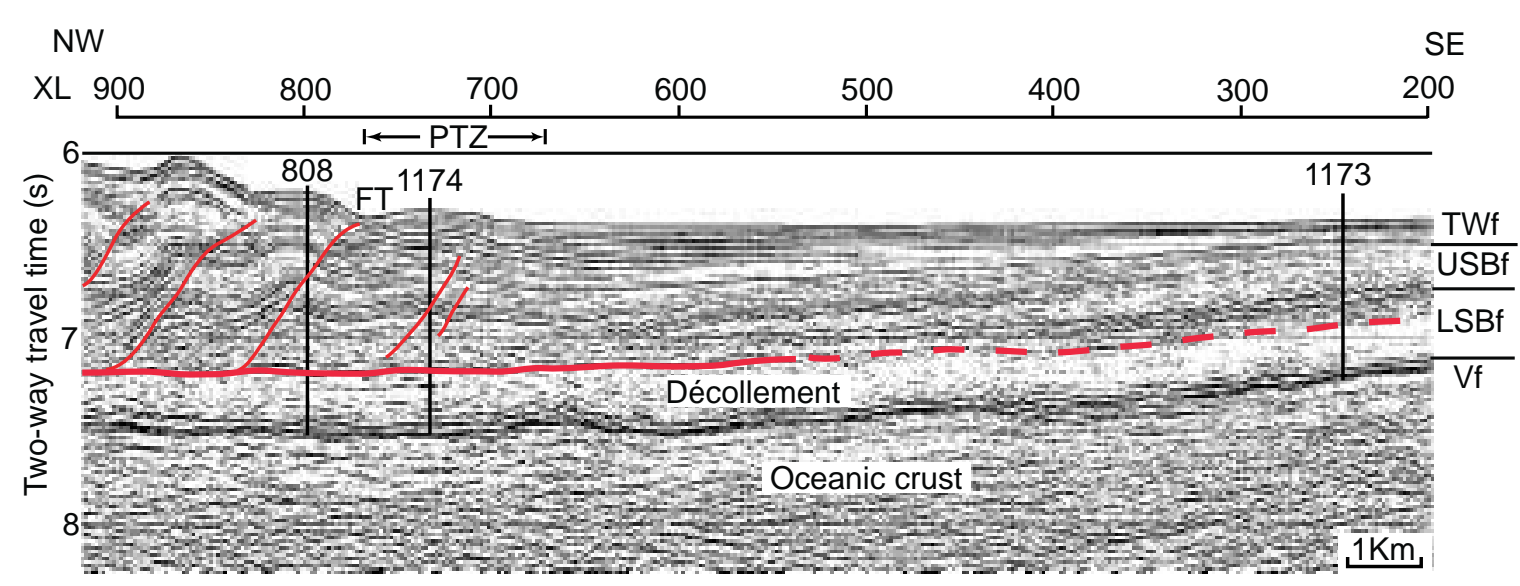

Figure 4. Seismic reflection profile through the Muroto Transect reference (Site 1173) and prism toe sites (Sites 1174 and 808). Correlation of sedimentary facies to the seismic data is shown on the right. Seismic data are from the 3-D seismic survey of Moore et al. [2001]. XL (cross line) identifies the crossing line number in the 3-D seismic volume. The location of the profile is shown in Figure 3. TWf, trench wedge facies; USBf, upper Shikoku Basin facies; LSBf, lower Shikoku Basin facies; Vf, volcaniclastic facies; FT, frontal thrust; PTZ, proto-thrust zone.

embayment of the trench landward slope (Figure 3; Okino and Kato [1995]). Yamazaki and Okamura [1989] interpreted this embayment as an indentation caused by the collision of seamounts with the prism. Recent seismic reflection work and ocean-bottom seismometer experiments on crustal structure support this interpretation [Park et al., 1999, 2000; Kodaira et al., 2000]. Most of Leg 190's drill sites fall along the southwestern boundary of this embayment, thus providing valuable information on this feature's unique characteristics.

[15] The Nankai Trough has historically generated earthquakes larger than magnitude $(M) 8$ at intervals of $\sim 180$ years [Ando, 1975, 1991]. The most recent one occurred in 1946 and ruptured offshore of Kii Peninsula and Shikoku. The Leg 190 Sites are located close to the seaward limit of the rupture zone of the 1946 Nankai earthquake estimated by Ando [1991]. Hyndman et al. [1995, 1997] found a correlation between the observed extent of a seismogenic zone and the thermal regime, especially in the Nankai Trough subduction zone. The updip limit of the seismogenic zone was found to coincide generally with the estimated location of the $150^{\circ} \mathrm{C}$ isotherm, and the downdip limit was found to coincide with the $350^{\circ}-450^{\circ} \mathrm{C}$ isotherm. They proposed that the updip limit coincides with the completion of the smectiteillite transition and the downdip limit coincides with the initiation of ductile deformation of quartz or serpentinization of peridotite mantle.

\section{Leg 190 Scientific Results}

[16] Coring on Leg 190 was carried out along two regional transects, the Muroto Transect, south of Shikoku Island's Cape Muroto, and the Ashizuri Transect, south of Cape Ashizuri (Figures 2 and 3). The basic structure of these two transects was outlined by two-dimensional (2-D) seismic reflection and refraction data (Figures 4 and 5) [Aoki et al., 1982; Moore et al., 1990, 1991; Stoffa et al., 1992]. New threedimensional (3-D) seismic data obtained over the Muroto Transect in 1999 [Moore et al., 2001] defined several tectonic domains in the accretionary prism along the Muroto Transect 


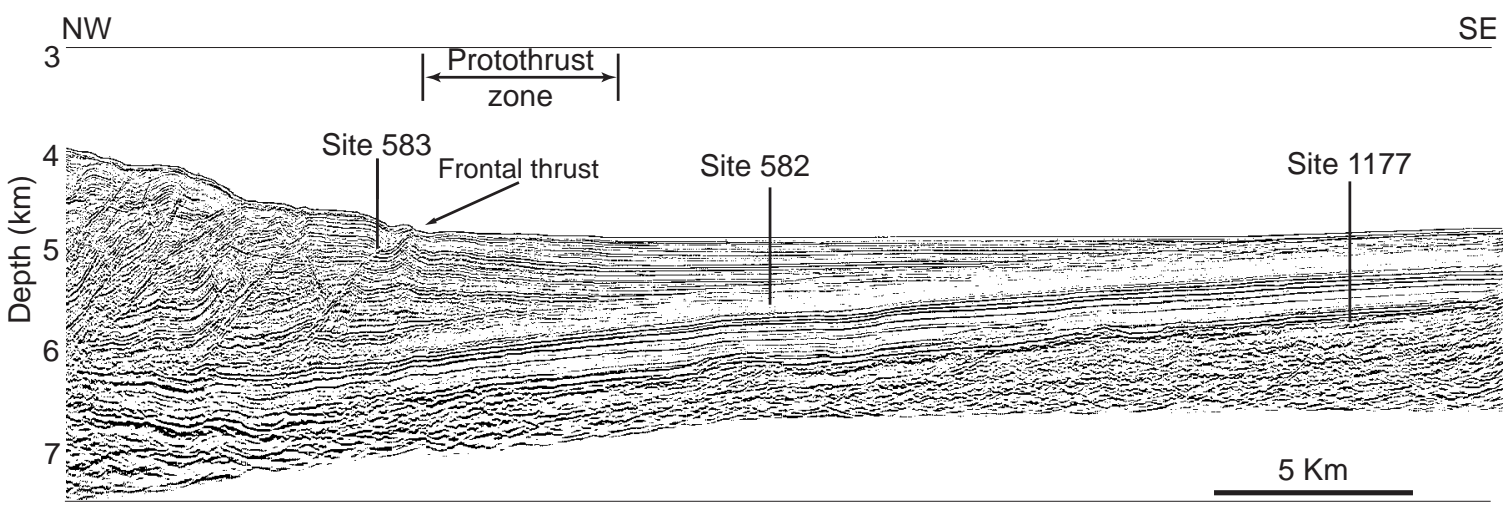

Figure 5. Seismic reflection profile (NT-2) through Ashizuri Transect reference site (Site 1177), trench site (Site 582), and prism toe site (Site 583).

(Figure 6). These domains and the locations of ODP sites from the Philippine Sea plate landward are the Shikoku Basin (Site 1173), Nankai Trough axis zone (Trench), protothrust zone (PTZ; Site 1174), imbricate thrust zone (ITZ; Site 808), frontal out-of-sequence thrust zone (FOZ), large thrust slice zone (LTSZ; Sites
1175 and 1176), and landward-dipping reflector zone (LDRZ; Site 1178).

\subsection{Stratigraphic Framework}

[17] Results from Leg 190 help to define several important spatial and temporal differences in the

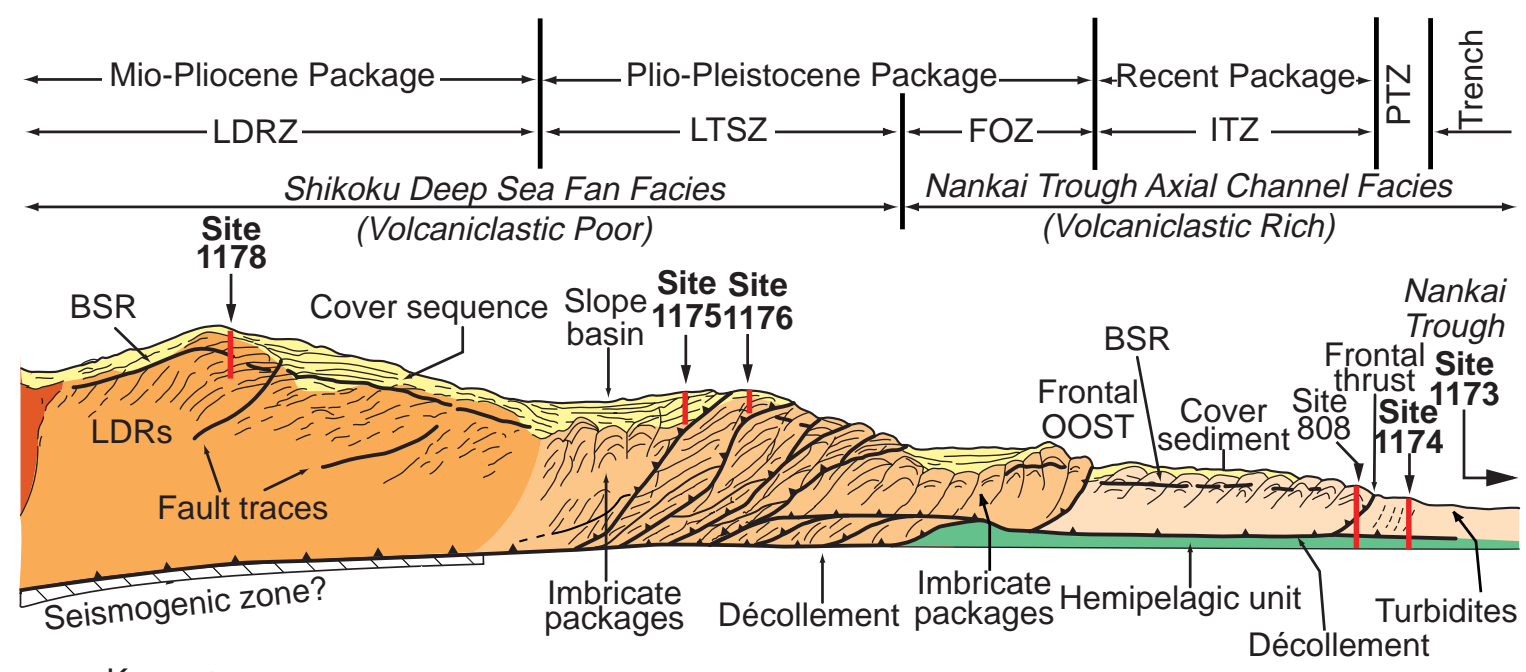

$\stackrel{0 \quad \mathrm{Km} \quad 10}{ } \mathrm{VE}=\sim 3 \mathrm{x}$

Figure 6. Schematic tectonic interpretation of a seismic line through the Leg 190 drill sites in the Muroto Transect. The profile is a composite line constructed from the 3-D survey (Figure 3) and crosses each of the drill sites (see Moore et al. [2001] for exact location). LDRs, landward-dipping reflections; BSR, bottom-simulating reflection; OOST, out-of-sequence thrust; PTZ, Proto-thrust zone; LDRZ, landward-dipping reflector zone; LTSZ, large thrust slice zone; FOZ, frontal out-of-sequence thrust zone; ITZ, imbricate thrust zone. 


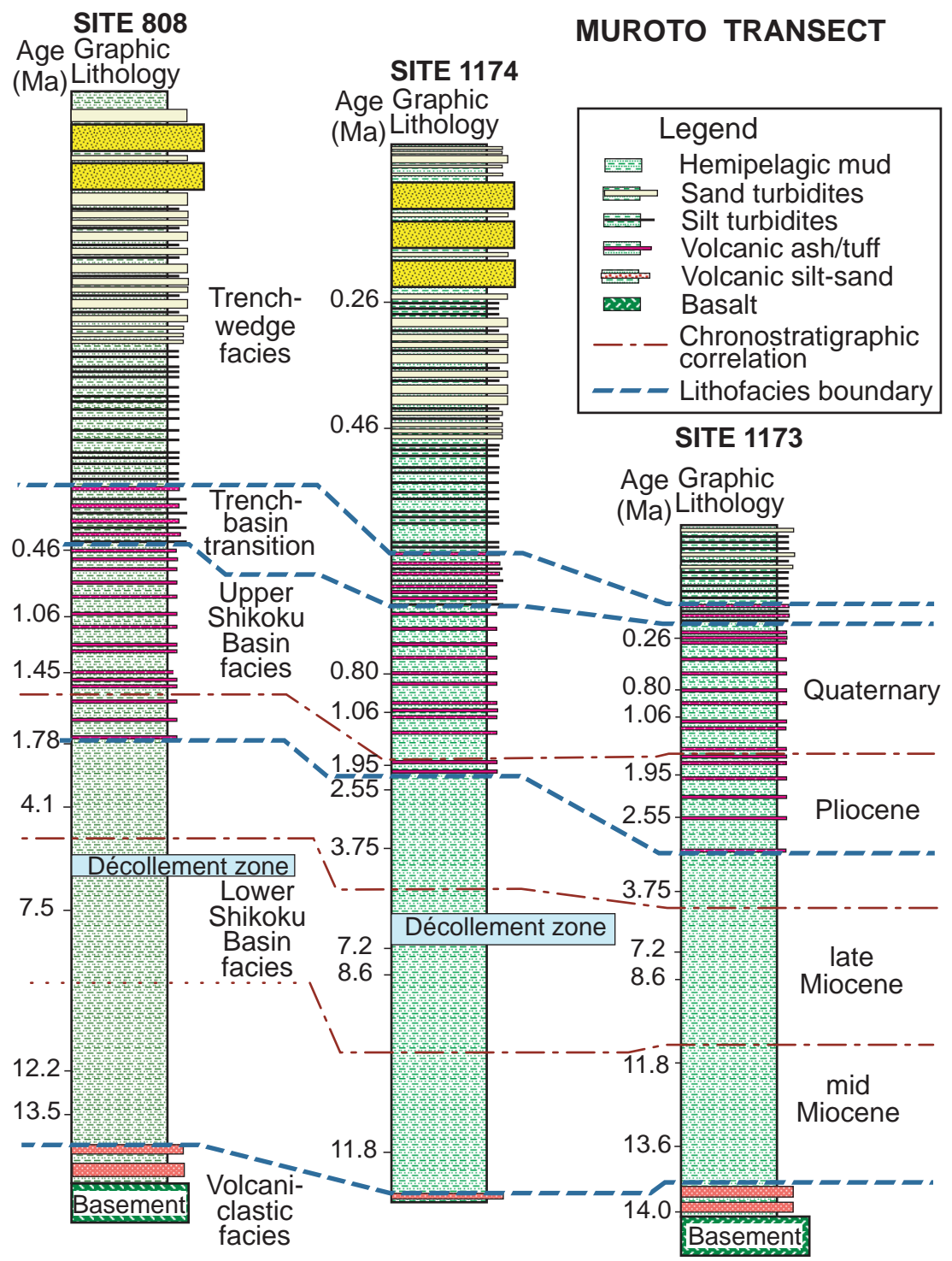

Figure 7. (a). Correlation of facies units and major time boundaries within stratigraphic successions of the reference and prism toe sites at the Muroto Transect. Time boundaries are in red (solid line) and facies boundaries are in blue (solid line). Data for ODP Site 808 are from Taira et al. [1991]. Note that the effects of facies imbrication along the frontal thrust of Site 808 have been removed. (b). Correlation of facies units and major time boundaries within stratigraphic successions of the reference and prism toe sites at the Ashizuri Transect of the Nankai margin. Time boundaries are in red (solid line) and facies boundaries are in blue (solid line). Data for DSDP Site 297 are from Ingle et al. [1973]. Data for DSDP Site 582 are from Kagami et al. [1986].

stratigraphy of the subducting Shikoku Basin sedimentary section. In turn, these stratigraphic variations influence patterns of deformation within the Nankai subduction system. Stratig- raphy at Sites 1173 and 1174 is very similar to that at Site 808 (Figures 4 and 7a). Site 1177 penetrated a deeper facies not encountered in the Muroto Transect. Beginning at the stratigraphic 


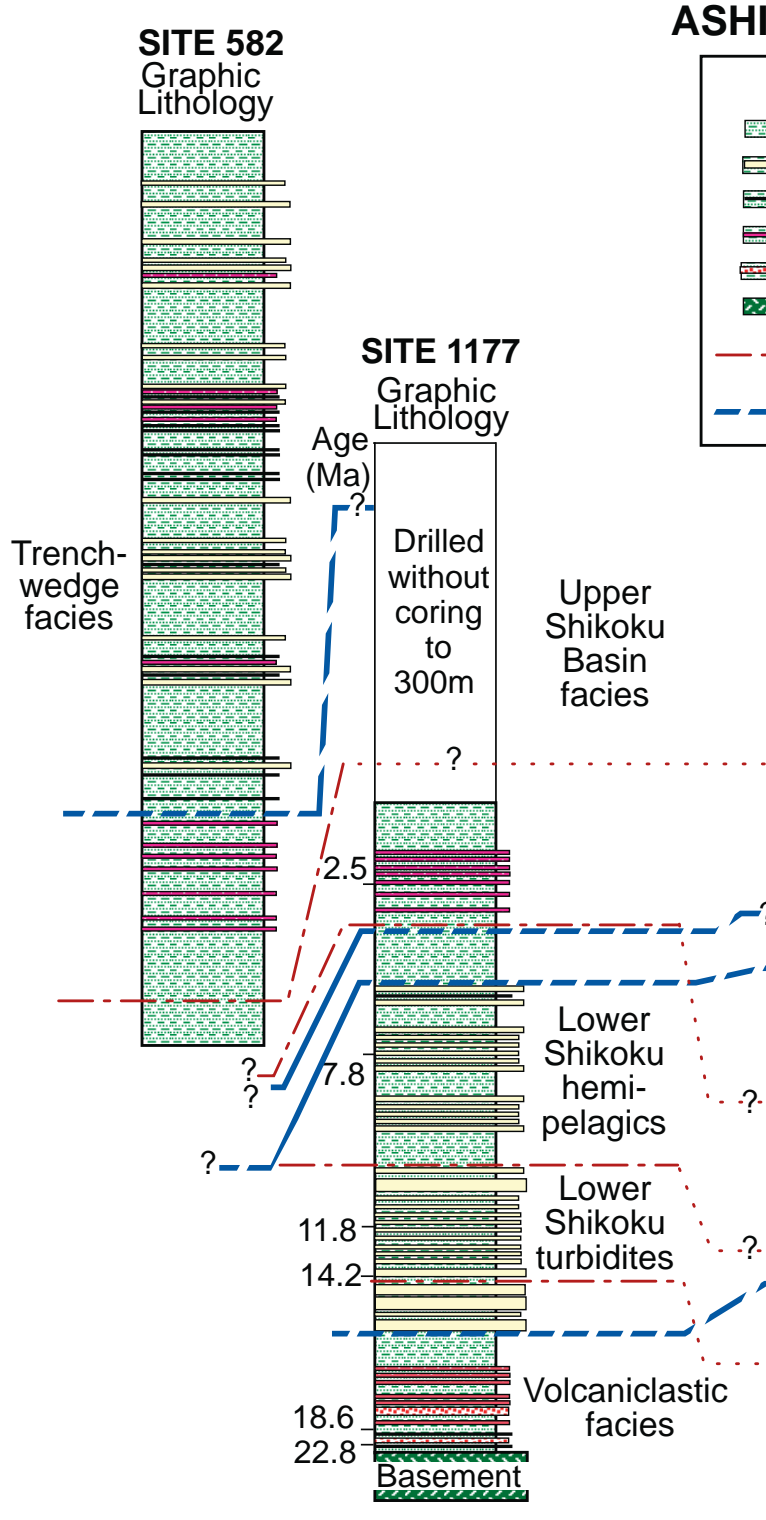

ASHIZURI TRANSECT

Legend

Hemipelagic mud

$\rightleftharpoons$ Sand turbidites

Silt turbidites

Volcanic ash/tuff

Volcanic silt-sand

Basalt - Chronostratigraphic correlation

- Lithofacies boundary

SITE 297

Graphic

Lithology

and

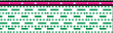

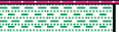

Quaternary

……

고료

$v^{-3}$ s

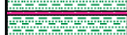

Pliocene

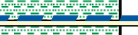

in

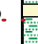

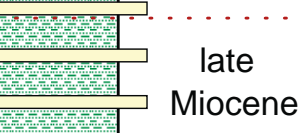

in

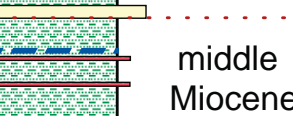

......

early

Not

cored

Miocene

Figure 7. (continued)

base, a volcaniclastic-rich facies overlies basalt basement at Site 1177 (Ashizuri Transect; Figures 5 and $7 b$ ). This facies differs from basal strata at Sites 808 and 1173 (Muroto Transect) in three important ways. First the oldest strata at Site 1177 are early Miocene in age, rather than middle Miocene as in the Muroto Transect. Second they contain considerable amounts of siliciclastic silt and sand in addition to volcanic sand and ash. Third the hemipelagic mudstones contain higher percentages of smectite. The age variation in basal sediment from west to east can 


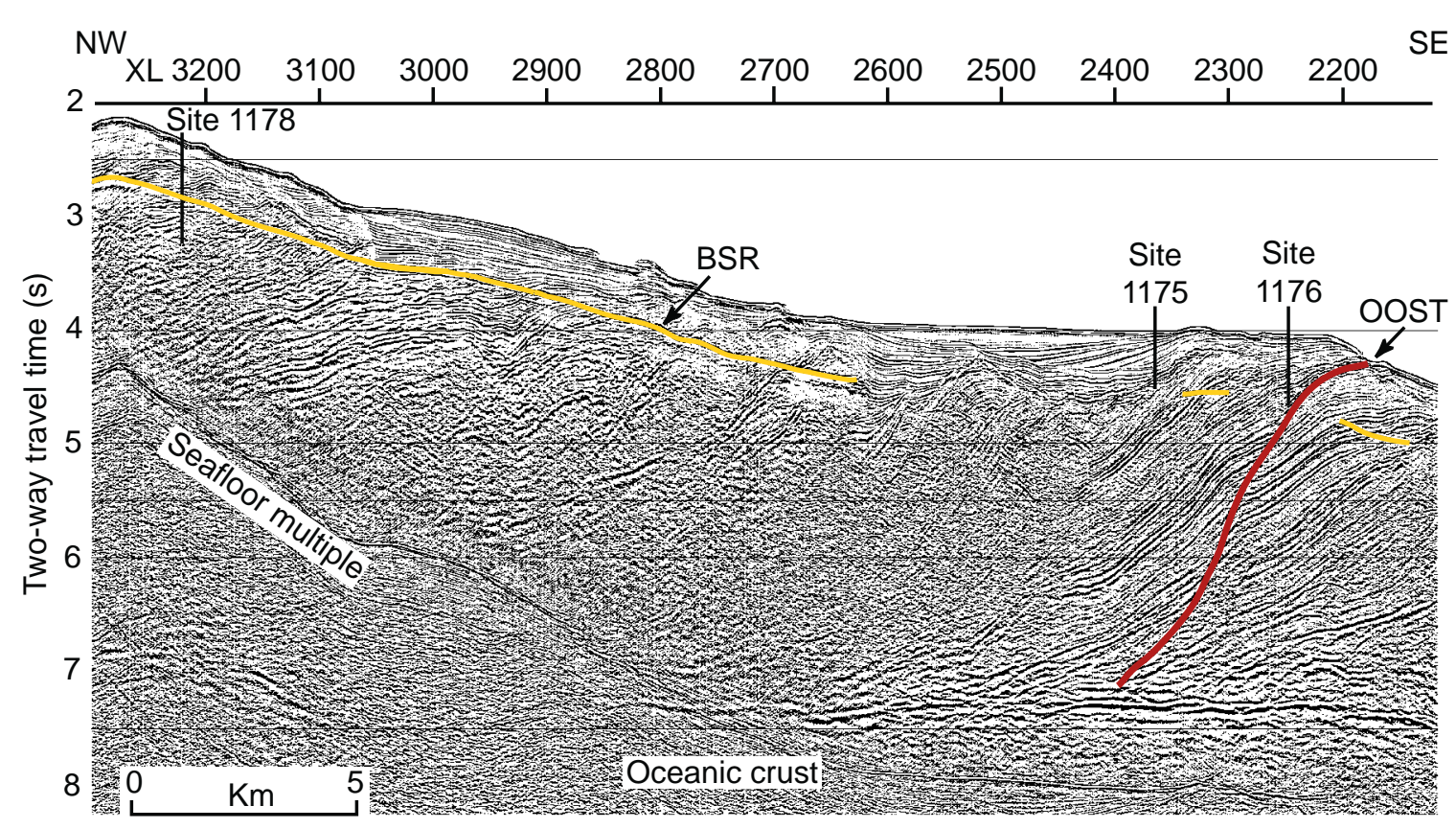

Figure 8. Seismic reflection profile through the Muroto Transect slope Sites 1175, 1176, and1178. Seismic data are from the 3-D seismic survey of Moore et al. [2001]. XL (cross line) identifies the crossing line number in the 3-D seismic volume. The location of the profile is in the center of the 3D survey shown in Figure 3. BSR, bottom simulating reflection.

be explained by proximity to the axis of the spreading ridge of Shikoku Basin. The ridge was active between 26 and $15 \mathrm{Ma}$, but seamount eruptions along the Kinan chain may have continued to 13-12 Ma [Okino et al., 1994].

[18] A package of lower (?) to upper Miocene siliciclastic turbidites with abundant woody organic matter overlies the basal volcaniclastic unit at Site 1177. Hemipelagic mudstone interbeds are enriched locally in expandable clay minerals (smectites). Deposition of correlative turbidites at Deep Sea Drilling Project (DSDP) Site 297, located in the Shikoku Basin southeast of our drilling transect, also began during the Miocene but continued into the Pliocene.

[19] A facies change from the lower to upper Shikoku Basin is defined at all sites by the sudden appearance of ash beds containing recognizable volcanic glass shards. Particle size, chemical composition, temperature, depth of burial, and time affect ash alteration and preservation. Thus this unit boundary is thought to be time transgressive and sensitive to regional and temporal changes in the margin's thermal structure.

[20] Shikoku Basin strata experienced diachronous burial during the Pliocene and Quaternary beneath an upward-coarsening and upwardthickening wedge of trench turbidites. The Nankai Trench wedge is thinner in the Muroto Transect area (above the basement high), but individual turbidites tend to be thinner and finer grained toward the southwest (DSDP Site 582). Quaternary sedimentation rates at Sites 1173 and 1174 were 600 and $760 \mathrm{~m} / \mathrm{Myr}$, respectively, more than 1 order of magnitude higher 


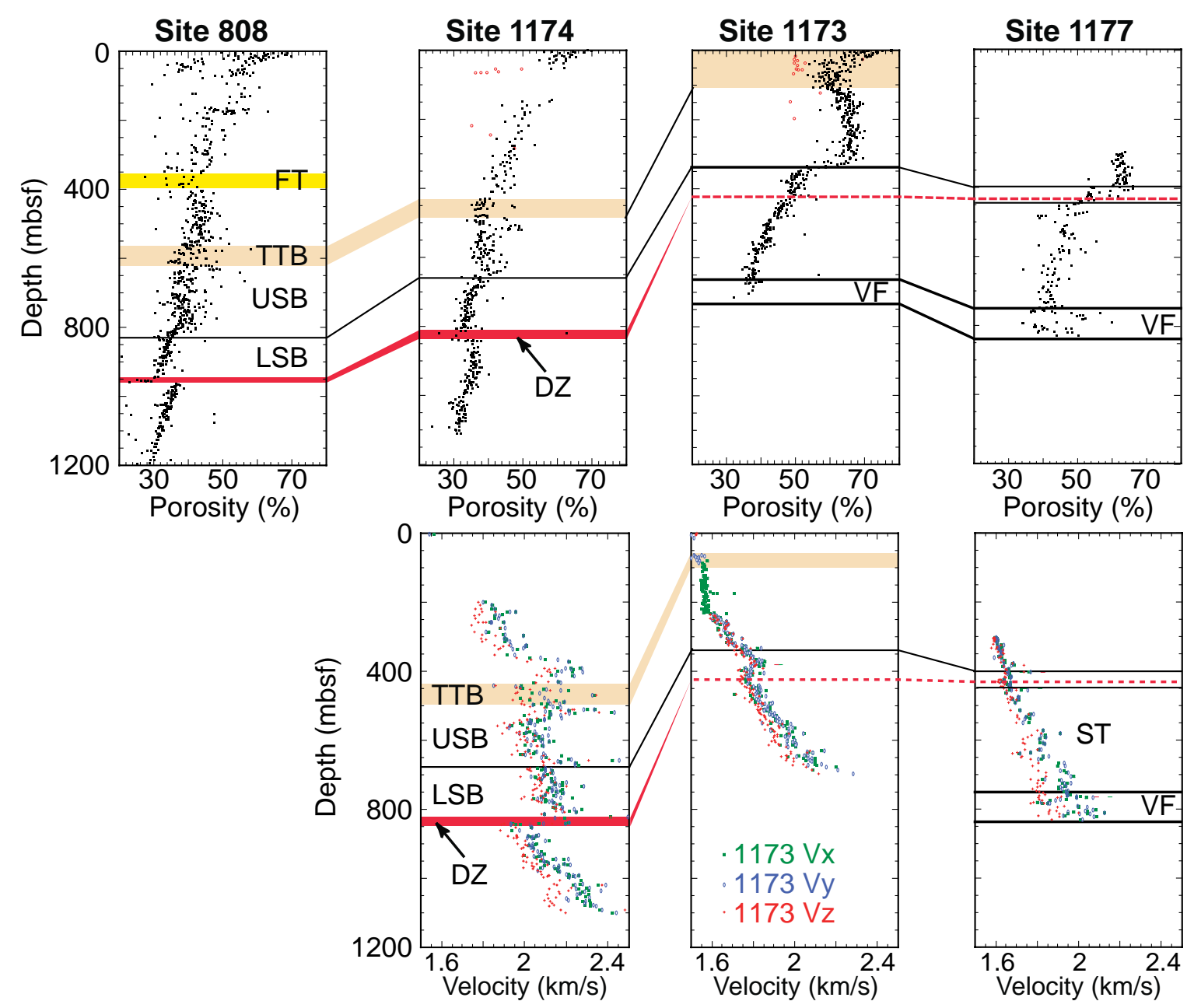

Figure 9. Porosities and velocities across the Muroto Transect (Sites 1173, 1174, and 808) and Ashizuri reference site (Site 1177). Lithologic units and major structural features are shown. The décollement location is shown by red shading where it was observed and by a dashed line at the stratigraphically equivalent depth at the reference sites. VF, volcaniclastic facies; DZ, décollement zone; ST, Shikoku turbidites; LSB, lower Shikoku Basin facies; USB, upper Shikoku Basin facies; TTB, trench-to-basin transition; FT, frontal thrust.

than the rate for the Miocene turbidites at Site 1177 (35.5 m/Myr).

[21] The boundary between the upper and lower Shikoku Basin sequences at Sites 1173 and 1174 occurs in strata 2-3 Myr old. Magnetic susceptibilities proved a valuable tool for correlation among sites (Figure 7) and help constrain the correlation of the décollement and incipient décollement horizons at Sites 1173,
1174,808 , and 1177 . The age of the décollement zone at Site 1174 is estimated from detailed bio- and magnetostratigraphic data to be from $5.894 \mathrm{Ma}$ (beginning of C3A Chron) to 6.935 Ma (termination of C3B Chron, which corresponds with that of the décollement zone at Site 808).

[22] Our upper slope Sites 1175 and 1176 cored completely through the slope sedi- 
a

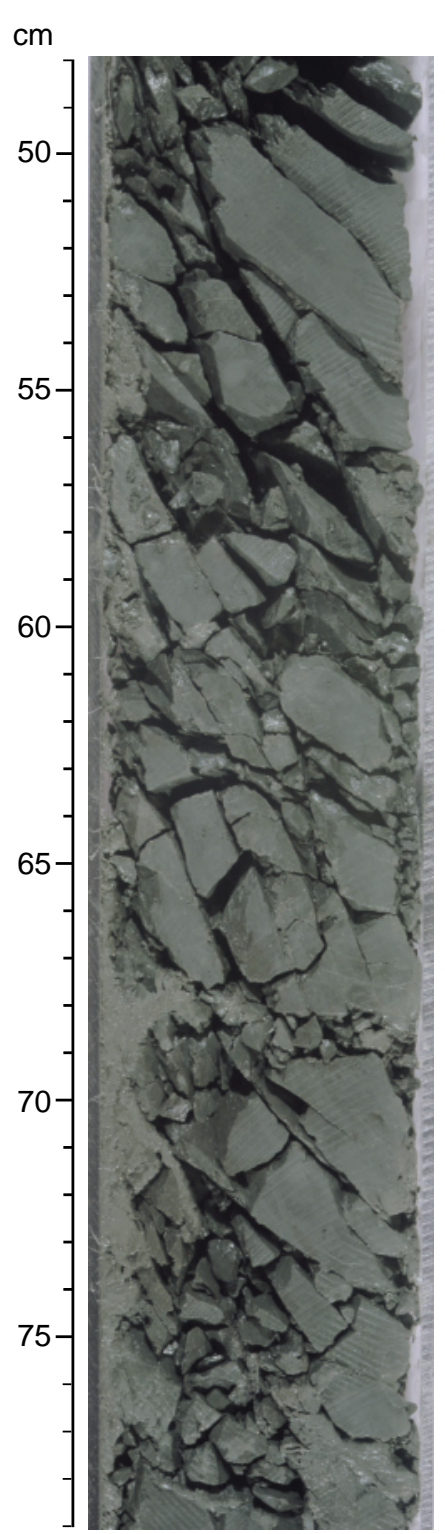

b

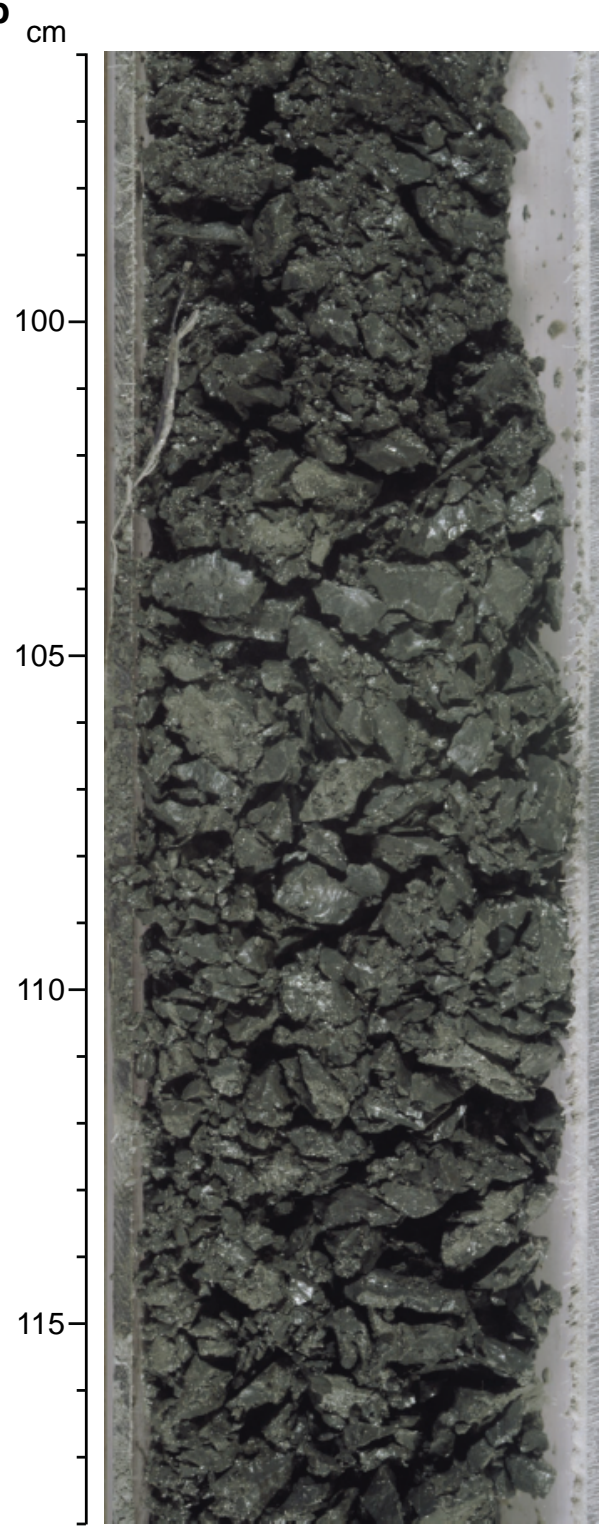

Figure 10. (a) Photograph of the upper part of décollement zone, showing breakage into angular blocks along inclined fractures (interval 190-1174B-71R-2, 48-79 cm). (b) Photograph of the lower part of décollement zone, showing comminution of sediments (interval 190-1174B-73R-1, 96-118 cm).

ments covering the LTSZ and penetrated into the underlying accretionary prism (Figure 8), thus providing information on the history of accretion and deformation of the prism. The age of the oldest slope sediments directly overlying accreted material is less than 2 Myr, with no significant age break at the slope sediment-prism boundary. Thus the slope basin as sampled at Sites 1175 and 1176 must have been initiated less than 2 


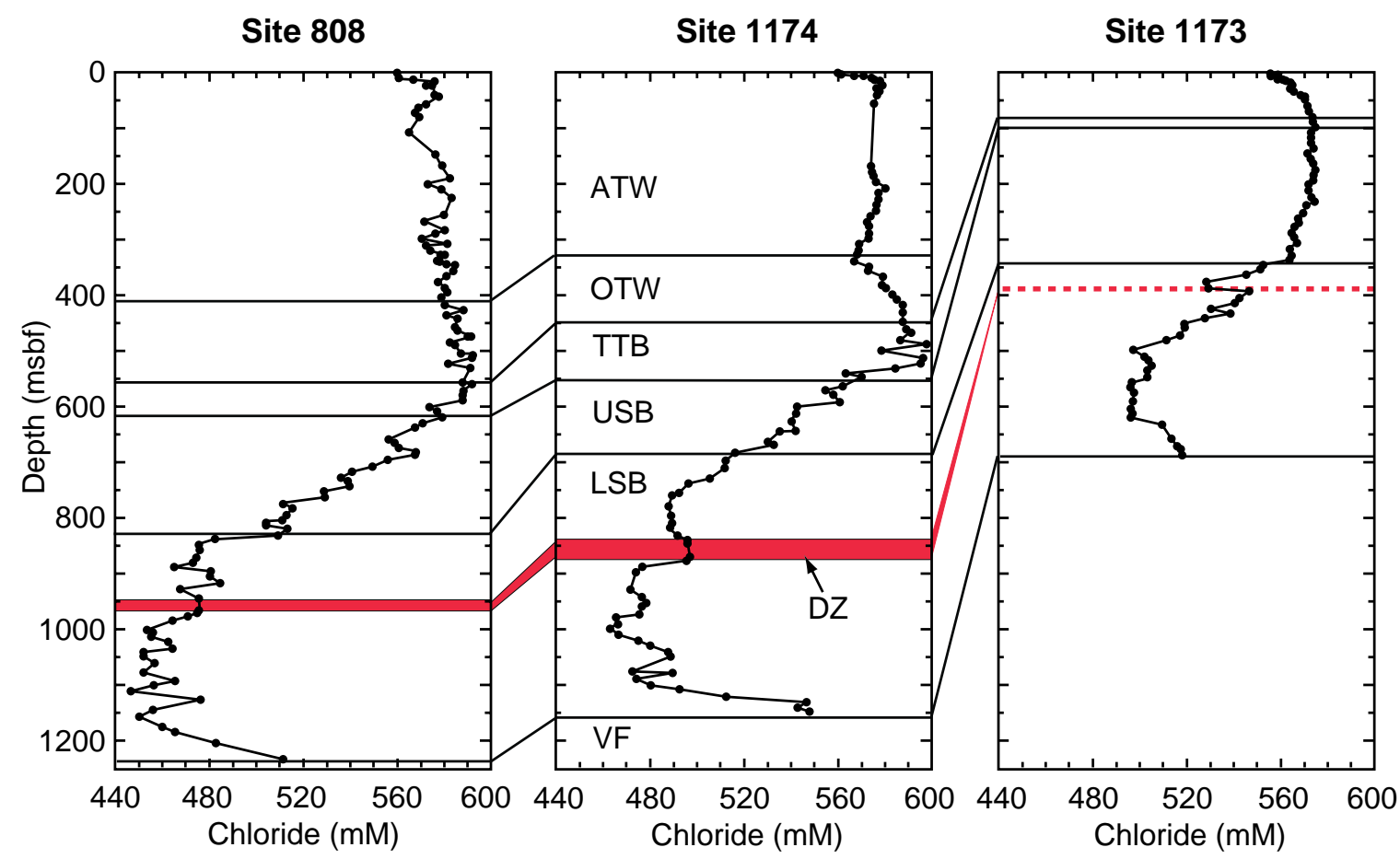

Figure 11. Chloride concentrations in interstitial water samples from the Muroto Transect reference (Site 1173) and prism toe sites (Sites 1174 and 808). VF, volcaniclastic facies; DZ, décollement zone; LSB, lower Shikoku Basin facies; USB, upper Shikoku Basin facies; TTB, trench-to-basin transition; OTW, outer trench wedge facies; ATW, axial trench wedge facies.

Ma, shortly after accretion of this part of the prism.

\subsection{Structural Development of the Décollement}

[23] Leg 190 completed a transect of the basal décollement of the Nankai accretionary prism from an undeformed state at Site 1173 to the well-developed fault zone landward of the deformation front documented at Sites 1174 and 808 (Figures 4, 7a, and 9). The hallmark of the $\sim 30 \mathrm{~m}$ thick décollement zone at Site 1174 , as well as the $\sim 20 \mathrm{~m}$ thick zone found at Site 808 , is intense brittle deformation, manifested as finely spaced fracturing of the mudstone into millimeter- to centimeter-scale fragments (Figure 10). The fragments have polished and slickenline surfaces, showing complex and heterogeneous slip directions, without obvious internal defor- mational structures at the core scale. At Site 1174, the top of the décollement zone was placed at a zone of prominent fracturing, although the lowermost prism section above exhibits distributed fracturing as well. Within the décollement zone, there is a downward increase in intensity of the brecciation, peaking in a 7-m-thick zone of fine comminution of the mudstone just above the very sharp base of the décollement. Despite the intensity of fracturing in the décollement, a deformation fabric defined by oriented shear surfaces is relatively well preserved in the drill cores (Figure 10). Within the fault zone, there are several intervals, up to tens of centimeters thick, of unbroken mud- 
stone, which are interpreted as intact blocks in a multistranded shear zone.

[24] Remarkably, the décollement zone at Site 1174 appears to be at least equally well developed as it is at the more landward Site 808. It is thicker at Site 1174 and also is brecciated to a much finer scale. Differences in the observed structures at the two locations could be explained by differences in core recovery; however, the greater thickness of the fault zone at Site 1174 is unexpected. Notable at both sites is the complete absence of veins, alteration zones, or other evidence of past fluid-rock interaction specific to the décollement.

[25] At Site 1173, there is no structural or physical properties evidence for incipient deformation in a proto-décollement zone. The stratigraphic equivalent to the Site 1174 décollement interval indicated in Figures 9 and 11 is based on correlation of core magnetic susceptibility signatures (Figure 7). This interval is part of a much thicker domain of increased bedding dip and fracturing but shows no localized increase in deformational features.

\subsection{Evolution of Physical Properties of Shikoku Basin Sediments}

[26] Physical properties changes within the Shikoku Basin sedimentary section document both compaction and diagenetic processes. At Site 1173, porosities increase slightly with depth from $57-65 \%$ at $\sim 102 \mathrm{mbsf}$ to $62-69 \%$ at $\sim 340$ mbsf (Figure 9). These values are surprisingly high for a burial depth of 300-400 m, and the porosity within the upper Shikoku Basin facies at both reference sites deviates significantly from normal compaction trends for silty clays. Velocities at Site 1173 remain relatively constant to $\sim 240 \mathrm{mbsf}$ and increase below this, despite the increasing porosity. This pattern suggests that the high porosities are supported by interparticle cementation. At Sites 808 and 1174 , a slight porosity increase with depth is observed in this unit but is less distinct than at Site 1173. Porosities within the upper Shikoku Basin facies at Sites 1174 and 808 range from $\sim 35$ to $45 \%$. The difference in porosity values between the reference sites and those in the deformed wedge imply that either compaction, collapse, and dewatering of the sediments has occurred during accretion or the sites within the accretionary wedge have a different diagenetic, cementation, and burial history than the current reference sites. High acoustic velocities were observed near the top and bottom of the upper Shikoku Basin facies, which is otherwise characterized by gradually increasing velocities with depth. At Site 1177, the lowermost $\sim 100 \mathrm{~m}$ of the upper Shikoku Basin facies exhibits nearly constant porosities of $60-65 \%$, whereas the $P$ wave velocities increase slightly with depth (Figure 9).

[27] Along the Muroto Transect (Sites 1173, 1174, and 808), porosities within the lower Shikoku Basin facies decrease with depth and follow a compaction trend typical of finegrained marine sediments (Figure 9). At Site 1173, porosities within this unit decrease from $\sim 50 \%$ at the top to $\sim 36 \%$ at its base. At Sites 1174 and 808 , where this unit is more deeply buried, porosities decrease from $34-40 \%$ to $30-35 \%$, with a sharp offset to greater porosity across the décollement. Porosities within the upper hemipelagic portion of the lower Shikoku Basin facies at Site 1177 (400-449 mbsf) decrease with depth from $60-65 \%$ to $46-54 \%$. If lithology is consistent between Sites 1173, 1174 , and 808 , the porosity decrease within the lower Shikoku Basin sequence from Site 1173 to Sites 1174 and 808 may be explained by compaction and dewatering of these sediments with progressive burial.

[28] The development of the décollement and the strain discontinuity across it are clearly 
exhibited in the core physical properties data (Figure 9). At Site 1174, there is a sharp porosity increase and $P$ wave velocity decrease immediately below the structurally defined décollement. These same features are even more pronounced at Site 808 [Taira et al., 1991; Moore and Shipley, 1993]. Site 808 exhibits evidence of a porosity minimum within the décollement; this pattern is not clearly exhibited at Site 1174. However, the most prominent feature at both sites is the physical properties discontinuity across the base of the zone crossing into the underthrust section. This discontinuity is likely due to a combination of undercompaction of the rapidly loaded underthrust section [Saffer et al., 2000; Screaton et al., 2001] and enhanced tectonic compaction of the prism and décollement caused by the imposition of lateral tectonic stress [Morgan and Karig, 1995].

[29] At Site 1173, there is no structural or physical properties evidence for incipient deformation in a proto-décollement zone. However, a marked downhole decrease in $P$ wave velocity and a slight porosity increase at the top of the interval ( 389 mbsf) suggest that a subtle mechanical strength discontinuity could contribute to future localization of the décollement in this interval.

[30] In accordance with the steadily decreasing porosities below the décollement zone, velocities generally increase with depth at Sites 808 and 1174. Horizontal velocities $\left(V_{x}\right.$ and $\left.V_{y}\right)$ increase more rapidly with depth below the décollement than vertical velocities $\left(V_{z}\right)$. Increasing velocity anisotropy with depth suggests vertical compaction of the sediments.

\subsection{Geochemical Gradients, Muroto Transect}

[31] The shipboard geochemical data provide insight on the origin of fluids and the depth intervals and paths of possible recent fluid flow. The most interesting and pronounced feature of the pore fluid concentration-depth profiles in the Muroto Transect from Site 1173 through Site 1174 to Site 808 is the $\sim 350-\mathrm{m}$ thick low-Cl zone within the lower Shikoku Basin unit (Figure 11). It has a clear concentration minimum $\sim 140 \mathrm{~m}$ below the décollement (or its equivalent at Site 1173). At Sites 1173 and 1174, this low-Cl zone decreases in intensity gradually upsection to the sediments overlying the upper Shikoku Basin facies. Additionally, the extent of $\mathrm{Cl}$ dilution relative to seawater $\mathrm{Cl}$ concentration systematically differs among the sites; it has evolved from $8-9 \%$ at reference Site 1173 to $16-17 \%$ at intermediate Site 1174 to $20-21 \%$ at adjacent $(<2 \mathrm{~km})$ Site 808 . Previous studies, based on data from Site 808 , demonstrated that transient fluid flow along the fault or a conduit within the underthrust section could explain the observed $\mathrm{Cl}$ profile [e.g., Kastner et al., 1993].

[32] Other potential fluid flow horizons characterized by sharp changes in downhole geochemical profiles occur (1) at Sites 1173, 1174 , and 808 , the boundary between the trench-wedge and upper Shikoku Basin sediments. The sharp reversal of the $\mathrm{Cl}$ gradient at this boundary may be maintained by flow of a slightly more saline fluid than seawater or by in situ hydration reactions that outpace diffusion. (2) They also occur along the protothrust $(\sim 470 \mathrm{mbsf})$ at Site 1174 , as particularly indicated by the $\mathrm{Cl}, \mathrm{Na}, \mathrm{Ca}$, and $\mathrm{K}$ concentration profiles. (3) At Site 1176, the $\mathrm{Cl}, \mathrm{Na}$, $\mathrm{Ca}$, and $\mathrm{K}$ concentration profiles suggest communication with a deep fluid source, possibly associated with the out-of-sequence thrust. It is interesting to note that the chemical characteristics of fluids from the protothrust at Site 1174 and the source potentially associated with the out-of-sequence thrust fault at Site 1176 are similar to the characteristics of the 
fluid in the low-Cl zone centered below the décollement.

[33] The dominant diagenetic processes are ash alteration to clays and zeolites and silicate (mostly clay) reactions at the deep water sites and carbonate reactions at the shallow water sites; carbonate diagenesis, however, also occurs at the deep-water sites. Opal-A dissolution controls the $\mathrm{Si}$ concentration profiles at each of the sites in the top few hundreds of meters, and other silicate reactions control it deeper in the sections.

\section{Discussion}

\subsection{Development of the Décollement Zone}

[34] The décollement beneath the toe of the Nankai accretionary prism along the Muroto transect develops from a rather homogeneous interval of hemipelagic mudstone at Site 1173 into a 20- to 32-m-thick zone of intense brittle deformation at Sites 1174 and 808. Where well developed, the fault zone resembles an anastomosing system of discrete brittle shears, similar to faults observed in mudrocks on land [ $\mathrm{Lab}$ aume et al., 1991]. The base of the décollement marks the boundary between the distinct physical/mechanical regimes of the prism and the underthrust section. Despite a major effort to detect localized fluid flow along the fault, there is no unambiguous evidence for flow of a chemically distinct fluid in the décollement zone along the transect defined by these three sites (see below).

[35] Although DSDP/ODP drilling has not penetrated the décollement along the Ashizuri Transect, a clear and continuous seismic reflector allows us to correlate the décollement horizon at the toe region to Site 1177, where it lies at $420 \mathrm{mbsf}, 30 \mathrm{~m}$ above a thick package of turbidites within the Lower Shi- koku Basin sequence (Figure 5). This projected décollement horizon at Site 1177 coincides in stratigraphic level with that identified on the Muroto Transect, based on chronological and magnetic susceptibility correlations (Figure 7). The apparent correlation of the décollement horizon between the Muroto and Ashizuri Transects suggests that the décollement regionally localizes consistently in a particular level in the lower Shikoku Basin mudstone.

[36] At both Sites 808 and 1174, porosities increase sharply across the décollement zone, whereas velocities decrease. This probably reflects a combination of (1) rapid, partially undrained burial of the underthrust sequence resulting in underconsolidation and (2) higher mean stress and tectonic compaction of the accreted sediments. At Site 1174, porosities directly below the décollement zone are slightly lower than at Site 808. This observation suggests that simple progressive compaction of underthrust sediments may not adequately explain the porosity-depth trends and that other factors (such as initial sediment thickness and heterogeneity in mechanical strength or the hydrologic properties of the décollement zone) are also important. At Site 1173 the stratigraphic equivalent interval of the décollement zone ( $\sim 390-420 \mathrm{mbsf})$ corresponds to the base of an anomalous zone in which velocities decrease with depth. A similar, considerably smaller amplitude velocity excursion correlates with the stratigraphic equivalent of the décollement at Site 1177 ( $\sim 430 \mathrm{mbsf})$.

\subsection{Diagenetic Control on Geochemical Profiles}

[37] The relative importance of fluid flow versus diagenetic reactions to explain the Muroto $\mathrm{Cl}$ profiles remains controversial. The coincidence of the rapid porosity transi- 
tion with freshening of the chloride profile near the transition from upper to lower Shikoku Basin sediments at reference Site 1173 poses the interesting possibility that geochemical anomalies (e.g., $\mathrm{Cl}$ and $\mathrm{Si}$ ) can result from sediment diagenesis as well as fluid flow. Similar $\mathrm{Cl}$ anomalies are also recognized at this stratigraphic boundary at Sites 1174 and 808. However, based on the residual smectite content of the sediment section at Site 808, the freshening cannot be attributed entirely to local smectite dehydration [Brown et al., 2001]. The freshening may result in part from transport of freshened fluids from greater depth [Saffer and Bekins, 1998] plus other local dehydration reactions of silicate phases. The low-Cl concentrations most likely reflect some combination of (1) in situ clay dehydration and other reactions, (2) the transport of freshened water from dehydration reactions at greater depth, and (3) transport of low $\mathrm{Cl}$ water from depth produced by the uptake of $\mathrm{Cl}$ by deep-seated hydrous silicate reactions; for example, serpentine, chlorite, talc, or amphibole incorporate considerable amounts of $\mathrm{Cl}$ in their structure [Kastner et al., 1993]. These latter reactions occur at temperatures of $>300^{\circ}$ and up to $\sim 500^{\circ} \mathrm{C}$. Thus the broad low-Cl zone signal is partially caused via $\mathrm{Cl}$ uptake by high-temperature hydrous silicate formation at depths equivalent to those of the seismogenic zone. However, significant lateral flow from depth would require permeabilities higher than are typical of hemipelagic sediments.

[38] The origin of slightly higher $\mathrm{Cl}$ concentration within the décollement zone, observed at Sites 1174 and 808, is unclear, but the inferred reactions can occur over a range of temperatures that coincide with conditions within the seismogenic zone. Leg 190 results thus allow us to recognize multiple influences on pore fluid geochemistry in this accretionary environment.

\subsection{Along-Strike Variations}

[39] The structural domains described above show variation along the strike of the prism. Along two parallel transects, separated by $\sim 100 \mathrm{~km}$, marked differences in prism architecture and structure are evident. The Ashizuri Transect, which includes Sites 582 and 583 (Leg 87) and Site 1177 (Figures 3, 5, and 7), displays a well-developed PTZ, containing a series of subparallel dipping discontinuities of unknown origin. These features are not evident within the Muroto Transect PTZ (Figure 4). Differences in prism taper (greater along the Ashizuri Transect than along the Muroto Transect) and seismic character of the décollement (strongly negative along Muroto Transect and positive along the Ashizuri Transect) suggest that the mechanical behavior of the prism differs along strike and that this variability may result from significant differences in mechanical properties and/or pore pressures at the two locations. Leg 190 results show that these differences could result from along-strike variations in the Shikoku Basin sedimentary sequence, such as the Miocene-Pliocene turbidite sequence that is present along the Ashizuri Transect but is absent along the Muroto Transect. We note also that the lower Shikoku Basin sequence in Ashizuri is more smectite-rich than off Muroto, which may have significant implications for the behavior of the deep seismogenic zone as this is the part of the section that is subducted beyond the prism toe.

\subsection{Rapid Growth of the Accretionary Prism}

[40] The upper slope sites dated the age of accretion of the LTSZ at less than $2 \mathrm{Ma}$. These sites are presently $40 \mathrm{~km}$ landward of the frontal thrust. If we assume steady state seaward growth of the prism over the past $2 \mathrm{Myr}$, the rate is $20 \mathrm{~km} / \mathrm{Myr}$. This is 3 times the rate of outbuilding in a comparable region of the eastern Aleutian accretionary prism $(\sim 20 \mathrm{~km}$ 
growth in $3 \mathrm{Myr}$; von Huene et al. [1998]). Our drilling transect is located adjacent to the large embayment in the accretionary prism (Figure 3 ). It is likely that the embayment was created by subduction of a large portion of the Kinan Seamount Chain [Yamazaki and Okamura, 1989]. Following passage of the seamount $\sim 2$ $\mathrm{Ma}$, the prism is rapidly re-establishing the zone of frontal accretion across the embayment.

\section{Conclusions}

[41] Leg 190 results provide insights into the interplay of sedimentation, tectonics, and fluid flow in an accretionary prism. At the six sites cored, lithostratigraphy and sediment diagenesis vary markedly in three dimensions throughout the Nankai-Shikoku Basin system. These variations in turn exert considerable influence on physical properties, hydrology, fluid-sediment geochemistry, and microbial activity.

[42] The large contrast among many key properties between the Muroto and Ashizuri Transects, including the diagenetic, lithologic, and geochemical character of the incoming sequences, may be tied to variations in mechanical, structural, and hydrologic behavior along the strike of this margin, thus explaining differences in prism taper and structural style along the two transects. In spite of these contrasts, we found that the décollement at both transects occurs at the level of an almost coeval horizon (6-7 Ma), suggesting that its position may be controlled by stratigraphy or subtle variations in physical properties. At Sites 1174 and 808, the décollement marks an abrupt increase in porosity (and a corresponding decrease in $P$ wave velocity), suggesting some combination of undercompaction below and overcompaction above.

[43] A broad low-chloride pore water anomaly was found in the lower section of the incoming, as well as accreted, sediments along the Muroto Transect, as first identified at Site 808. The progressive decrease in the magnitude of the low-chloride anomaly from prism to basin reflects a combination of in situ diagenesis and fluid migration. The fraction contributed by each is as yet undetermined, but fluid flow from depth is probably not as important in the Nankai prism as in other prisms, such as Barbados.

[44] Leg 190 provided age data on the accretionary history of the Nankai Trough prism for the first time and revealed a very rapid rate of growth of the prism during the Pleistocene. This is a major revision to previous estimates of the accretionary wedge growth and shows that the outer $40 \mathrm{~km}$ of the accretionary prism has been added to the Nankai margin over only $2 \mathrm{Myr}$, a rate that is more than 3 times that suggested for the eastern Aleutian prism.

\section{Acknowledgments}

[45] We wish to thank Tom Ribbens and the ship's crew, Scott Pedersen and the drilling crew, and Tom Pettigrew, Brad Julson and the other ODP staff aboard the D/V JOIDES Resolution for their tireless support that contributed greatly to the overall success of this program. Reviews by J. Casey Moore and an anonymous reviewer greatly improved the manuscript. This research used samples provided by the Ocean Drilling Program (ODP). The ODP is sponsored by the U.S. National Science Foundation (NSF) and participating countries under management of Joint Oceanographic Institutions (JOI), Inc. This research was partially supported by the U.S. Science Support Program.

\section{References}

Ando, M., Source mechanisms and tectonic significance of historical earthquakes along the Nankai Trough, Japan, Tectonophysics, 27, 119-140, 1975.

Ando, M., A fault model of the 1946 Nankaido earthquake derived from tsunami data, Phys. Earth Planet. Inter, 28, 320-336, 1991.

Aoki, Y., T. Tamano, and S. Kato, Detailed structure of the Nankai Trough from migrated seismic sections, in 
Studies in Continental Margin Geology, edited by J. S. Watkins and C. L. Drake, AAPG Mem., 34, 309-322, 1982.

Brown, K., D. Saffer, and B. Bekins, Smectite diagenesis, pore water freshening, and fluid flow at the toe of the Nankai wedge, Earth Planet. Sci. Lett., in press, 2001.

Davis, E. E., K. Becker, T. Pettigrew, B. Carson, and R. MacDonald, A hydrologic seal and downhole observatory for deep-ocean boreholes, Proc. Ocean Drill Program Initial Rep., 139, 43-53, 1992.

Hyndman, R. D., K. Wang, and M. Yamano, Thermal constraints on the seismogenic portion of the southwestern Japan subduction thrust, J. Geophys. Res., 100, 15,373-15,392, 1995.

Hyndman, R. D., M. Yamano, and D. A. Oleskevich, The seismogenic zone of subduction thrust faults, Isl. Arc, 6 , 244-260, 1997.

Ingle, J. C., et al., Inital Report Deep Sea Drilling Project, vol. 31, U.S. Govt. Print. Off., Washington, D.C., 1973.

Kagami, H., et al., Inital Report Deep Sea Drilling Project, vol. 87, U.S. Govt. Print. Off., Washington, D.C., 1986.

Kamata, H., and K. Kodama, Tectonics of an arc-arc junction: an example from Kyushu Island at the junction of the southwest Japan Arc and Ryukyu Arc, Tectonophysics, 233, 69-81, 1994.

Kano, K., H. Kato, Y. Yanagisawa, and F. Yoshida, Stratigraphy and geologic history of the Cenozoic of Japan, rep. 274, 114 pp., Geol. Surv. Jpn., 1991.

Karig, D. E., and C. L. Angevine, Geologic constraints on subduction rates in the Nankai Trough, Init.Rep. Deep Sea Drill.Proj., 87, 789-796, 1986.

Kastner, M., H. Elderfield, W. J. Jenkins, J. M. Gieskes, and T. Gamo, Geochemical and isotopic evidence for fluid flow in the western Nankai subduction zone, Japan, Proc. Ocean Drill Program Sci. Results, 131, 397413, 1993.

Kodaira, S., N. Takahashi, J. Park, K. Mochizuki, M. Shinohara, and S. Kimura, Western Nankai Trough seismogenic zone: Results from a wide-angle ocean bottom seismic survey, J. Geophys. Res., 105, 5887-5905, 2000 .

Labaume, P., C. Berty, and P. Laurent, Syndiagenetic evolution of shear structures in superficial nappes: An example from the northern Apennines, NW Italy, J. Struct. Geol., 13, 385-398, 1991.

Le Pichon, X., T. Iiyama, H. Chamley, J. Charvet, M. Faure, H. Fujimoto, T. Furuta, Y. Ida, H. Kagami, S. Lallemant, J. Leggett, A. Murata, H. Okada, C. Rangin, V. Renard, A. Taira, and H. Tokuyama, Nankai Trough and the fossil Shikoku Ridge: results of Box 6 Kaiko survey, Earth Planet. Sci. Lett., 83, 186-198, 1987.

Moore, G. F., and T. H. Shipley, Character of the décolle- ment in the Leg 131 area, Nankai Trough, Proc. Ocean Drill. Program, Sci. Results, 131, 73-82, 1993.

Moore, G. F., T. H. Shipley, P. L. Stoffa, D. E. Karig, A. Taira, S. Kuramoto, H. Tokuyama, and K. Suyehiro, Structure of the Nankai Trough accretionary zone from multichannel seismic reflection data, J. Geophys. Res., 95, 8753-8765, 1990.

Moore, G. F., D. E. Karig, T. H. Shipley, A. Taira, P. L. Stoffa, and W. T. Wood, Structural framework of the ODP Leg 131 area, Nankai Trough, Proc. Ocean Drill. Program Init. Rep, 131, 15-20, 1991.

Moore, G. F., A. Taira, N. L. Bangs, S. Kuramoto, T. H. Shipley, C. M. Alex, S. S. Gulick, D. J. Hills, T. Ike, S. C. Leslie, A. J. McCutcheon, K. Mochizuki, S. Morita, Y. Nakamura, J. O. Park, B. L. Taylor, H. Yagi, and Z. Zhao, Data report: Structural setting of the Leg 190 Muroto Transect, [CD-ROM], Proc. Ocean Drill. Program Init. Rep., 190, 1-14, 2001.

Morgan, J. K., and D. E. Karig, Décollement processes at the Nankai accretionary margin, Southeast Japan, $J$. Geophys. Res., 100, 15,221-15,231, 1995.

Niitsuma, N., Collision tectonics in the southern Fossa Magna, central Japan, Mod. Geol., 14, 3-18, 1989.

Okino, K., and Y. Kato, Geomorphological study on a clastic accretionary prism: The Nankai Trough, Isl. Arc., 4, 182-198, 1995.

Okino, K., Y. Shimakawa, and S. Nagaoka, Evolution of the Shikoku basin, J. Geomagn. Geoelectr., 46, 463479, 1994.

Okino, K., Y. Ohara, S. Kasuga, and Y. Kato, The Philippine Sea: New survey results reveal the structure and history of the marginal basins, Geophys. Res. Lett., 26, 2287-2290, 1999.

Park, J.-O., T. Tsuru, Y. Kaneda, Y. Kono, S. Kodaira, N. Takahashi, and H. Kinoshita, A subducting seamount beneath the Nankai accretionary prism off Shikoku, southwestern Japan, Geophys. Res. Lett., 26, 931-934, 1999.

Park, J.-O., T. Tsuru, S. Kodaira, A. Nakanisi, S. Miura, Y. Kaneda, and Y. Kono, Out-of-sequence thrust faults developed in the coseismic slip zone of the 1946 Nankai earthquake $(M w=8.2)$ off Shikoku, southwest Japan, Geophys. Res. Lett., 27, 1033-1036, 2000.

Saffer, D. M., and B. A. Bekins, Episodic fluid flow in the Nankai Accretionary Complex: Timescale, geochemistry, flow rates, and fluid budget, J. Geophys. Res., 103, 30,351-30,371, 1998.

Saffer, D. M., E. A. Silver, A. T. Fisher, H. Tobin, and K. Moran, Inferred pore pressures at the Costa Rica subduction zone: Implication for dewatering processes, Earth Planet. Sci Lett., 177, 193-207, 2000.

Screaton, E., D. Saffer, P. Henry, S. Hunze, and Leg 190 Shipboard Scientific Party, Porosity loss within the un- 
derthrust sediments of the Nankai accretionary complex: Implications for overpressures, Geology, in press, 2001.

Seno, T., The instantaneous rotation vector of the Philippine Sea Plate relative to the Eurasian Plate, Tectonophysics, 42, 209-226, 1977.

Stoffa, P. L., W. T. Wood, T. H. Shipley, G. F. Moore, E. Nishyama, M. A. B. Bothelo, A. Taira, H. Tokuyama, and K. Suyehiro, Deepwater high-resolution expanding spread and split spread marine seismic profiles in the Nankai Trough, J. Geophys. Res., 97, 1687-1713, 1992.

Taira, A., and N. Niitsuma, Turbidite sedimentation in the Nankai Trough as interpreted from magnetic fabric, grain size, and detrital modal analyses, Inital Rep. Deep Sea Drill. Proj, 87, 611-632, 1986.

Taira, A., I. Hill, J. V. Firth, et al., Proceedings of the Ocean Drilling Program, Inital Reports, vol.131, Ocean Drill. Prog., College Station, Tex., 1991.

Taira, A., J. Katto, M. Tashiro, M. Okamura, and K. Kodama, The Shimanto Belt in Shikoku, Japan-evolution of Cretaceous to Miocene accretionary prism, Mod. Geol., 12, 5-46, 1988.

Taira, A., I. Hill, J. Firth, U. Berner, W. Brückmann, T. Byrne, T. Chabernaud, A. Fisher, J.-P. Foucher, T.
Gamo, J. Gieskes, R. Hyndman, D. Karig, M. Kastner, Y. Kato, S. Lallement, R. Lu, A. Maltman, G. Moore, K. Moran, G. Olaffson, W. Owens, K. Pickering, F. Siena, E. Taylor, M. Underwood, C. Wilkinson, M. Yamano, and J. Zhang, Sediment deformation and hydrogeology of the Nankai Trough accretionary prism: Synthesis of shipboard results of ODP Leg 131, Earth Planet. Sci. Lett., 109, 431-450, 1992.

Takahashi, M., Large felsic magmatism of the Miocene outerzone of southwest Japan (in Japanese), Earth Mon. Spec., Vol. 23, 160-168, 1999.

Taylor, B., Rifting and the volcanic-tectonic evolution of the Izu-Bonin-Mariana Arc, Proc. Ocean Drill. Program Sci. Results, 126, 627-651, 1992.

Underwood, M. B., R. Orr, K. Pickering, and A. Taira, Provenance and dispersal patterns of sediments in the turbidite wedge of Nankai Trough, Proc. Ocean Drill. Program Sci. Results, 131, 15-34, 1993.

von Huene, R., D. Klaeschen, M. Gutscher, and J. Fruehn, Mass and fluid flux during accretion at the Alaska Margin, Geol. Soc. Am. Bull., 110, 468-482, 1998.

Yamazaki, T., and Y. Okamura, Subducting seamounts and deformation of overriding forearc wedges around Japan, Tectonophysics, 160, 207-229, 1989. 